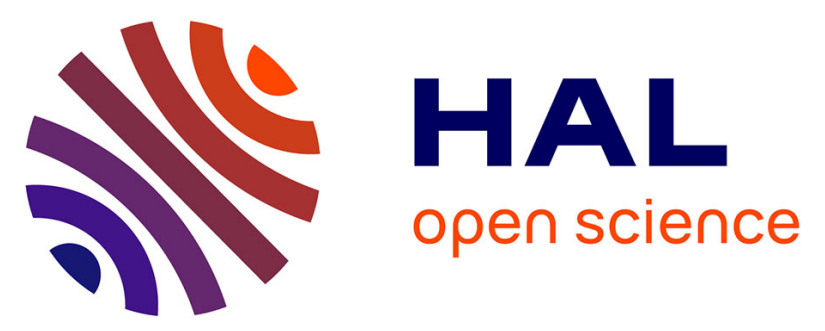

\title{
Unconventional surface plasmon resonance signals reveal quantitative inhibition of transcriptional repressor EthR by synthetic ligands
}

Céline Crauste, Nicolas Willand, Baptiste Villemagne, Marion Flipo, Eve Willery, Xavier Carette, Martin Moune Dimala, Anne-Sophie Drucbert, Pierre-Marie Danze, Benoit Deprez, et al.

\section{To cite this version:}

Céline Crauste, Nicolas Willand, Baptiste Villemagne, Marion Flipo, Eve Willery, et al.. Unconventional surface plasmon resonance signals reveal quantitative inhibition of transcriptional repressor EthR by synthetic ligands. Analytical Biochemistry, 2014, 452, pp.54-66. 10.1016/j.ab.2014.02.011 . hal-02309788

\section{HAL Id: hal-02309788 \\ https://hal.science/hal-02309788}

Submitted on 9 Oct 2019

HAL is a multi-disciplinary open access archive for the deposit and dissemination of scientific research documents, whether they are published or not. The documents may come from teaching and research institutions in France or abroad, or from public or private research centers.
L'archive ouverte pluridisciplinaire HAL, est destinée au dépôt et à la diffusion de documents scientifiques de niveau recherche, publiés ou non, émanant des établissements d'enseignement et de recherche français ou étrangers, des laboratoires publics ou privés. 


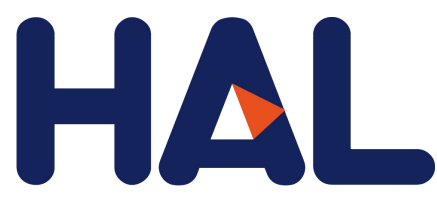

archives-ouvertes

\section{Unconventional surface plasmon resonance signals reveal quantitative inhibition of transcriptional repressor EthR by synthetic ligands}

Céline Crauste, Nicolas Willand, Baptiste Villemagne, Marion Flipo, Eve Willery, Xavier Carette, Martin Dimala, Anne-Sophie Drucbert, Pierre-Marie Danze, Benoit Deprez, et al.

\section{To cite this version:}

Céline Crauste, Nicolas Willand, Baptiste Villemagne, Marion Flipo, Eve Willery, et al.. Unconventional surface plasmon resonance signals reveal quantitative inhibition of transcriptional repressor EthR by synthetic ligands. Analytical Biochemistry, 2014, 452, pp.54-66. 10.1016/j.ab.2014.02.011 . hal-02309788

\section{HAL Id: hal-02309788 \\ https://hal.archives-ouvertes.fr/hal-02309788}

Submitted on 9 Oct 2019

HAL is a multi-disciplinary open access archive for the deposit and dissemination of scientific research documents, whether they are published or not. The documents may come from teaching and research institutions in France or abroad, or from public or private research centers.
L'archive ouverte pluridisciplinaire $\mathbf{H A L}$, est destinée au dépôt et à la diffusion de documents scientifiques de niveau recherche, publiés ou non, émanant des établissements d'enseignement et de recherche français ou étrangers, des laboratoires publics ou privés. 


\title{
Unconventional surface plasmon resonance signals reveal quantitative inhibition of transcriptional repressor EthR by synthetic ligands
}

\author{
Céline Crauste a,b,c,d,e Nicolas Willand $^{\text {a,b,c,d,e,* }}$, Baptiste Villemagne ${ }^{\text {a,b,c,d,e }}$, Marion Flipo ${ }^{\text {a,b,c,d,e }}$, \\ Eve Willery $^{\text {c,e,f }}$, Xavier Carette ${ }^{\text {ce, }, f}$, Martin Moune Dimala ${ }^{\text {c,e,f }}$, Anne-Sophie Drucbert ${ }^{g}$, Pierre-Marie Danze ${ }^{g}$, \\ Benoit Deprez ${ }^{\mathrm{a}, \mathrm{b}, \mathrm{c}, \mathrm{d}, \mathrm{e}}$, Alain R. Baulard ${ }^{\mathrm{c}, \mathrm{e}, \mathrm{f}, *}$ \\ ${ }^{a}$ Biostructures and Drug Discovery, INSERM U761, F-59000 Lille, France \\ ${ }^{\mathrm{b}}$ Faculté de Pharmacie de Lille, University of Lille Nord de France, F-59000 Lille, France \\ ${ }^{\mathrm{c}}$ Institut Pasteur de Lille, F-59019 Lille, France \\ ${ }^{\mathrm{d}}$ IFR 142, Molecular and Cellular Medicine, F-59021 Lille, France \\ e PRIM, F-59019 Lille, France \\ ${ }^{\mathrm{f}}$ Center for Infection and Immunity of Lille, INSERM U1019-CNRS UMR 8204, University of Lille Nord de France, F-59000 Lille, France

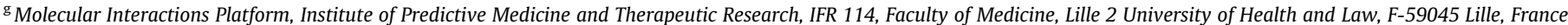

\section{A R T I C L E I N F O}

\section{Article history:}

Received 30 September 2013

Received in revised form 4 February 2014

Accepted 7 February 2014

Available online 20 February 2014

\section{Keywords:}

Surface plasmon resonance

EthR

Tuberculosis

Transcriptional regulator

TetR

SPR negative signal

\begin{abstract}
A B S T R A C T
EthR is a mycobacterial repressor that limits the bioactivation of ethionamide, a commonly used anti-tuberculosis second-line drug. Several efforts have been deployed to identify EthR inhibitors abolishing the DNA-binding activity of the repressor. This led to the demonstration that stimulating the bioactivation of Eth through EthR inhibition could be an alternative way to fight Mycobacterium tuberculosis. We propose a new surface plasmon resonance (SPR) methodology to study the affinity between inhibitors and EthR. Interestingly, the binding between inhibitors and immobilized EthR produced a dose-dependent negative SPR signal. We demonstrate that this signal reveals the affinity of small molecules for the repressor. The affinity constants $\left(K_{\mathrm{D}}\right)$ correlate with their capacity to inhibit the binding of EthR to DNA. We hypothesize that conformational changes in EthR during ligand interaction could be responsible for this SPR signal. Practically, this unconventional result opens perspectives onto the development of an SPR assay that would at the same time reveal structural changes in the target upon binding with an inhibitor and the binding constant of this interaction.
\end{abstract}

Tuberculosis is one of the most frightening illnesses on the planet. There were an estimated 8.6 million new $\mathrm{TB}^{1}$ cases in 2012, including 1.1 million cases among people infected with HIV, and 1.3 million people died from TB that year [1]. Next to HIV infection, demographic factors, poor living conditions, and neglected TB control in many countries caused this pandemic. There is an urgent need for new drugs and new strategies to eliminate more efficiently sensitive or drug-resistant strains. We have recently validated the mycobacterial transcriptional repressor EthR as a new target to fight

* Corresponding authors at: Institut Pasteur de Lille, F-59019 Lille, France. Fax: +33 320964709 (N. Willand). Fax: +33 320871158 (A. Baulard).

E-mail addresses: nicolas.willand@univ-lille2.fr (N. Willand), alain.baulard@ pasteur-lille.fr (A.R. Baulard).

${ }^{1}$ Abbreviations used: SPR, surface plasmon resonance; TB, tuberculosis; NTA nitrilotriacetic acid; CM5 chip, carboxymethylated chip; $\mathrm{Me}_{2} \mathrm{SO}$, dimethyl sulfoxide; EDTA, ethylenediaminetetraacetic acid; NHS, $N$-hydroxysuccinimide; TSA, thermal shift assay; HTH, helix-turn-helix; SA, streptavidin; EDC, $N$-ethyl- $N^{\prime}$-(3-diethylaminopropyl)carbodiimide hydrochloride; RU, resonance unit tuberculosis. EthR belongs to the TetR/CamR family of transcriptional regulators and negatively regulates the expression of ethA in Mycobacterium tuberculosis [2]. The ethA gene encodes a flavin-containing monooxygenase that catalyzes the bioactivation of ethionamide, one of the most commonly used anti-TB second-line drugs [3,4].

We have shown that in vitro and in vivo allosteric inhibition of the interaction between EthR and the ethA promoter with a druglike compound was able to improve ethionamide efficacy, which in mice allowed for a therapeutic dose reduction [5-7]. In the past few years, several efforts have been made to identify and optimize EthR inhibitors [5-10]. To that end, interactions between EthR and synthetic inhibitors have been studied using a large panel of biological and biophysical assays such as X-ray crystallography [7], thermal shift assay detecting the thermostabilization effect of the ligand on the protein $[8,11]$, and finally surface plasmon resonance (SPR) [2,5-7].

Using the SPR biosensor assay, the interaction between biomolecules immobilized on a sensor surface and biomolecules or small 
chemical entities flowing over the chip in an aqueous buffer is quantified by measuring variations in refractive index. Interactions on the gold surface of the biosensor chip between two partners increase the electron density around the sensor surface and in most cases induce positive changes in the refractive index, translated as a real-time SPR signal called a sensorgram (resonance unit as function of time) [12]. SPR is an ideal tool to generate high-quality data on the interactions between biomolecules, as well as between small ligands and biomolecules. Direct binding assay based on SPR presents many advantages: it is label-free, has a low target consumption, and provides real time analysis and detection of low-affinity target binders [13].

As an efficient tool to study inhibitors of EthR, we previously designed a bioanalytical assay based on SPR. SPR was used to measure the capacity of inhibitors to disturb the interaction between EthR and its DNA operator (DNA/EthR SPR methodology) [2,5-7]. Although very useful to quantify the capacity of EthR ligand to inhibit the DNA binding function of EthR, this approach was unsuitable for revealing the binding constants that drive the direct interactions between EthR and the inhibitors, which allowed only fragmentary comparisons between compounds. Then, to further characterize our EthR inhibitors by accessing binding constants $\left(K_{\mathrm{D}}\right)$, we immobilized the transcriptional repressor EthR on a CM5 carboxymethylated sensor chip and monitored the interaction with EthR inhibitors in solution (ligand/EthR SPR methodology). We report here an SPR assay focusing on the direct ligand/ transcriptional repressor interactions to compare chemical series of new EthR inhibitors. This assay produced unconventional negative SPR signals that we demonstrate to be specific for the ligand/ protein interaction. We discuss the hypothesis that this signal could be predictive of the allosteric structural changes undergone during ligand/protein interaction and examine the implications of this observation in the context of target-based drug screening.

\section{Materials and methods}

SPR experiments were carried on a BIAcore 3000 instrument (GE HealthCare). Thermal shift assay (TSA) experiments were performed on a LightCycler 480 instrument (Roche). Research-grade CM5, SA (streptavidin), and NTA (nitrilotriacetic acid) sensors were purchased from GE HealthCare. HBS-EP (10 mM Hepes, $150 \mathrm{mM}$ $\mathrm{NaCl}, 3 \mathrm{mM}$ EDTA, $0.005 \%$ surfactant P20) was purchased from GE HealthCare and used with various sodium chloride concentrations. All chemicals used (Tris- $\mathrm{HCl}, \mathrm{NaCl}$, EDTA, DTT (dithiothreitol), NHS ( $N$-hydroxysuccinimide), EDC ( $N$-ethyl- $N$ '-(3-diethylaminopropyl)carbodiimide hydrochloride), ethanolamine, and Sypro orange) were of the highest grade available commercially.

Plasmid construction and $\mathrm{His}_{6}$-EthR and $\mathrm{His}_{6}$-EthR-mutant expression and purification

\section{Construction of plasmid pET-15b-ethR}

The N-terminally hexahistidine-tagged EthR was produced in Escherichia coli C41 (pET-15b-ethR) and purified as described. The DNA coding for EthR was amplified by PCR using M. tuberculosis H37Rv chromosomal DNA as template and oligonucleotides 0-183, 5' -CATATGACCACCTCCGCGGCCAGT-3', and O-184, 5'-GGAT CCGAGCACCCCCGACCGAGT-3', as primers. The PCR product was inserted into pCR2.1Topo (Invitrogen) to generate pCR2.1-ethR. The EthR-encoding fragment was sequenced on both strands and then isolated from pCR2.1-ethR by digestion with NdeI and BamHI and inserted into pET-15b (Novagen), yielding pET-15b-ethR. This plasmid encodes EthR containing an extra amino-terminal tag with

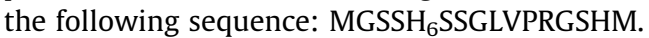

Construction of plasmid pET-15b-eth $R_{G 106 W}$

A first PCR product was obtained by amplification using $M$. tuberculosis H37Rv chromosomal DNA as template and oligonucleotides 0-275 (5'-AGGACCGTCCGCTGGCCGATA-3') and 0-276 (5'-AACA CGTTGATCCAGGTGCGCCACA- $3^{\prime}$ ) as primers, thus introducing a point mutation at codon 106 of ethR (underlined in oligonucleotide O-276), resulting in the replacement of glycine 106 by a tryptophan residue. This 216 -bp fragment was used as a $5^{\prime}$ primer in association with oligonucleotide 0-278 (5'-GCTTCCTTTCGGGCTTTGTTAGCAG$3^{\prime}$ ) to amplify a 594-bp fragment, which was subsequently inserted into PCRII-Topo (Invitrogen) to generate pCRIIethRG106W. The 275-bp Sall-Sall fragment of pET-15b-ethR [2] was then exchanged for the equivalent fragment of pCRIlethRG106W to produce pET$15 \mathrm{~b}-e t h R_{\mathrm{G} 106 \mathrm{~W}}$. The orientation of the fragment was checked by restriction digestion and the DNA sequence was confirmed by sequencing of the entire open reading frame.

Production and purification of $\mathrm{His}_{6}$-EthR and mutant $\mathrm{His}_{6}-\mathrm{EthR}_{\mathrm{G106W}}$ N-terminally hexahistidine-tagged EthR WT or G106W was produced in E. coli C41 using the protein expression plasmids pET-15b-ethR and pET-15b-eth $R_{\mathrm{G} 106 \mathrm{~W}}$, respectively, as previously described [2]. Bacteria were grown in $100 \mathrm{ml} \mathrm{LB}$ broth to an $\mathrm{OD}_{600 \mathrm{~nm}}$ of 0.6-0.7. Isopropylthiogalactoside was then added to a final concentration of $1 \mathrm{mM}$ and the culture was grown for $3 \mathrm{~h}$. The cells were harvested by centrifugation at $12,000 \mathrm{~g}$ at $4{ }^{\circ} \mathrm{C}$, resuspended in $10 \mathrm{ml}$ of lysis buffer $(50 \mathrm{mM}$ Tris- $\mathrm{HCl}, 300 \mathrm{mM}$ $\mathrm{NaCl}, \mathrm{pH} 7.5,10 \mathrm{mM}$ imidazole), and lysed by two passages at 6.2 MPa through a French press cell. After centrifugation $\left(20,000 \mathrm{~g}, 25 \mathrm{~min}, 4^{\circ} \mathrm{C}\right)$, the supernatant was recovered and $\mathrm{His}_{6^{-}}$ EthR or $\mathrm{His}_{6}-$ EthR $_{\mathrm{G106W}}$ was separated from the whole-cell lysate by Ni-NTA agarose chromatography (Qiagen). After three washing steps with lysis buffer, His $_{6}$-tagged proteins were eluted from the resin with $250 \mathrm{mM}$ imidazole in lysis buffer, dialyzed overnight against EthR buffer $(10 \mathrm{mM}$ Tris- $\mathrm{HCl}, 300 \mathrm{mM} \mathrm{NaCl}, \mathrm{pH} \mathrm{7.5}$, $1 \mathrm{mM}$ DTT, $0.1 \mathrm{mM}$ EDTA), and concentrated to $14 \mathrm{mg} / \mathrm{ml}$ for EthR and $7 \mathrm{mg} / \mathrm{ml}$ for EthR $\mathrm{G}_{\mathrm{G} 106 \mathrm{~W}}$. Protein purity was controlled by Coomassie blue staining after SDS-PAGE on a $12 \%$ polyacrylamide gel. Protein concentration was evaluated using the Bio-Rad protein assay kit. Purified proteins $\mathrm{His}_{6}$-EthR and $\mathrm{His}_{6}-\mathrm{EthR}_{\mathrm{G} 106 \mathrm{~W}}$ were stored in EthR buffer at $4{ }^{\circ} \mathrm{C}$.

\section{Production of biotinylated double-stranded DNA fragments}

The 106-bp fragment overlapping the ethA- $R$ intergenic region $\left(D_{N A} A_{\text {tha-r }}\right.$ ) was obtained from M. tuberculosis H37Rv chromosomal DNA using 0-270, 5'-CGGTCATGGATCCACGCTATCAAC-3', and 0-271, 5'-biotin-CTGACTGGCCGCGGAGGTGGT-3'. The biotinylated double-stranded 113-bp-long irrelevant DNA fragment (+14 to +127 ) of the E. coli bla gene was PCR amplified using oligonucleotides 0-343, 5'-TTTCCGTGTCGCCCTTATTCC-3', and 0-344, 5' -CCAC TCGTGCACCCAACTGAT-3', and pUC18 as substrate (DNA ${ }_{\text {nonspecific }}$ ). The amplified biotinylated fragments were purified on a QiaQuick column (Qiagen), cloned, and sequenced.

\section{SPR assay for determining EthR/ligand affinity}

Immobilization of EthR and EthR $R_{G 106 W}$ on CM5 sensor chip

All SPR experiments were performed at $25^{\circ} \mathrm{C}$. Capture of EthR and $E_{\text {thR }} \mathrm{G}_{\mathrm{G} 106 \mathrm{~W}}$ was performed on $\mathrm{CM} 5$ sensor chips with a carboxymethylated dextran matrix using an HBS-EP running buffer (10 mM Hepes, pH 7.4, 150 mM NaCl, 3 mM EDTA, 0.005\% surfactant P20). The chip was first activated by injecting a fresh mixture (35 $\mu \mathrm{l}, 50 / 50, v / v$ ) of $0.1 \mathrm{mM}$ NHS and $0.4 \mathrm{mM}$ EDC at a flow rate of $5 \mu \mathrm{l} / \mathrm{min}$. Several $5-\mu \mathrm{l}$ injections of EthR or $\mathrm{EthR}_{\mathrm{G} 106 \mathrm{~W}}$, respectively at 15 and $30 \mu \mathrm{g} / \mathrm{ml}$, in $10 \mathrm{mM}$ acetate buffer, pH 4.5, were performed so as to reach the desired level of covalently attached 
protein $(1000,2000,4000,7000$, or 10000 resonance units (RU)). Noncovalently bound esters were deactivated by injection of $35 \mu \mathrm{l}$ of $1 \mathrm{M}$ ethanolamine hydrochloride, $\mathrm{pH} 8.5$, followed by a surface wash with a $0.03 \%$ SDS solution.

\section{Real-time binding experiment for EthR/ligand interaction on CM5}

Binding experiments were performed with a constant flow rate of $20 \mu \mathrm{l} / \mathrm{min}$ using HBS-EP buffer $(10 \mathrm{mM}$ Hepes, $350 \mathrm{mM} \mathrm{NaCl}$, $0.005 \%$ surfactant P20, $3 \mathrm{mM}$ EDTA, $1 \% \mathrm{Me}_{2} \mathrm{SO}$ ) as the running buffer. Experiments were performed on a CM5 sensor functionalized with $4000 \mathrm{RU}$ of EthR $\mathrm{G}_{\mathrm{G} 106 \mathrm{~W}}$ on the reference flow cell (F1) and with the equivalent amount of EthR on the analysis flow cell (F2). Ligands were injected at atleast six different concentrations over both channels. The range of concentrations was selected from 0 , $0.1,0.33,1,3,6,9,27,60,81,121,243 \mu \mathrm{M}$, depending on the solubility of the ligand (visual test in the running buffer) and on the minimal concentration necessary to observe a signal. All experiments were repeated at least three times and each concentration was tested in triplicate. The final sample concentration of $\mathrm{Me}_{2} \mathrm{SO}$ was $1 \%$. The samples were injected over $2,5,9$, or $16 \mathrm{~min}$. The injection time was chosen so as to observe the equilibrium state for at least two concentrations. As all the ligands were able to dissociate from the protein during the course of the running buffer on the surface, we avoided injection of a regeneration solution to preserve the sensor chip. Dissociation times up to 20 min were applied to recover the initial baseline level between injections of the various ligands at increasing concentrations. This dissociation time was increased as long as necessary for high-affinity ligands such as BDM41907 and BDM44831. The binding sensorgrams were obtained from the subtraction F2-F1.

\section{Data analysis for $K_{D}$ determination}

For all the ligands studied the $K_{\mathrm{D}}$ was determined using the following method: the sensorgrams were analyzed using BIAevaluation software version 4.0.1. As the software cannot interpret a negative sensorgram, the curves were mirrored by multiplication of the data by -1 . Subtraction of a blank sensorgram, obtained by injecting ligand buffer, was performed before each series of analysis to correct for bulk effect and other systematic artifacts. The corresponding data were fitted using all concentrations simultaneously and both association and dissociation curves were fitted simultaneously. For all ligands analyzed, the one-to-one Langmuir model provided adequate fitting. In the following equation, A represents the analyte in solution, $B$ the protein immobilized, and $A B$ the complex formed by the interaction on the chip:

$\mathrm{A}+\mathrm{B} \underset{k_{\text {off }}}{\stackrel{k_{\text {on }}}{\leftrightarrows}} \mathrm{AB}$.

The adequateness of the fit was judged by the values of the $\chi^{2}$ (lower than $5 \%$ of the $R_{\max }$ ) and the randomness of residue distribution. The association rate constant $\left(k_{\text {on }}\right)$ and the dissociation rate constant $\left(k_{\text {off }}\right)$ were derived from the optimal binding model using BIAevaluation software. The dissociation constant $K_{\mathrm{D}}$ was calculated based on the ratio of $k_{\text {off }} / k_{o n}$.

\section{$K_{D}$ calculated from $R U$ values at the equilibrium state}

For the fit validation, some $K_{\mathrm{D}}$ values were also extrapolated from graph with the response (RU) at the equilibrium state as a function of the ligand concentration. Normalization, fit, and detection of the inflection point of the curves were performed using GraphPad Prism 5.0. to determine $K_{\mathrm{D}}$ values.

\section{SPR analysis of ligand/EthR interaction on NTA sensor chip}

Analysis of ligand/EthR interaction on NTA was performed in four steps using a $50 \mu \mathrm{M}$ EDTA HBS-EP running buffer at $10 \mu \mathrm{l} /$ min: activation of the surface, immobilization of $\mathrm{His}_{6}$-EthR, injection of the ligand, and elimination of the protein from the surface. Activation of the NTA surface was performed in channel F2 using<smiles>CS(=O)(=O)c1ccc(-c2noc(C3CCN(C(=O)CCCC(F)(F)F)CC3)n2)cc1</smiles>

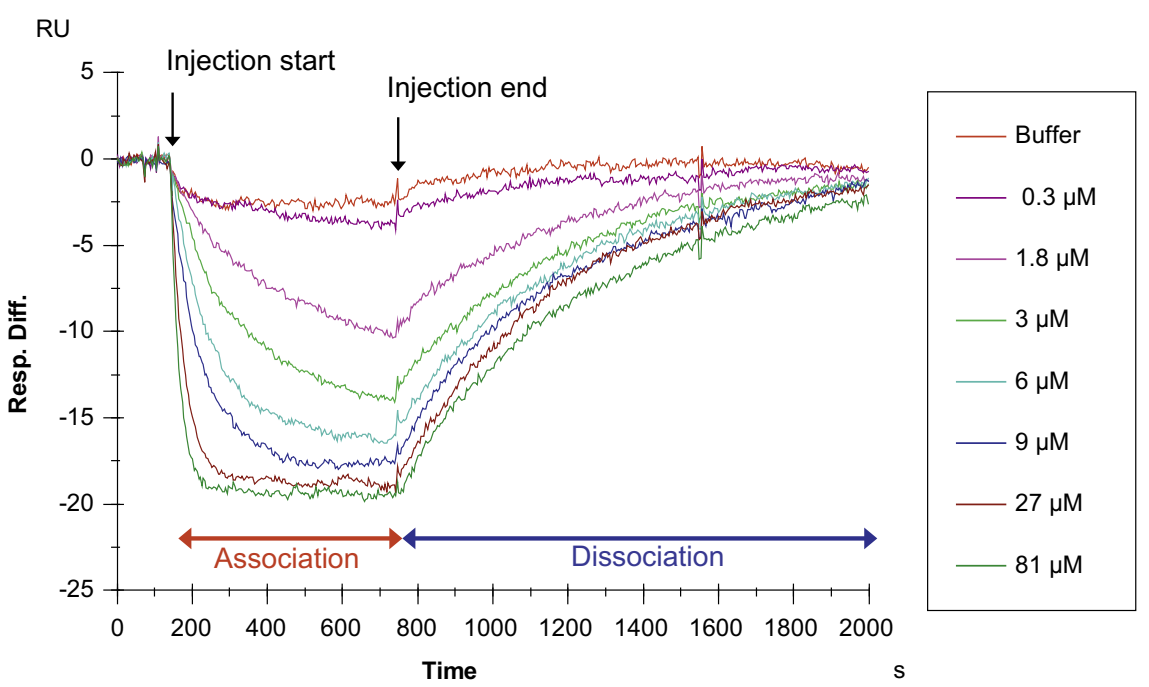

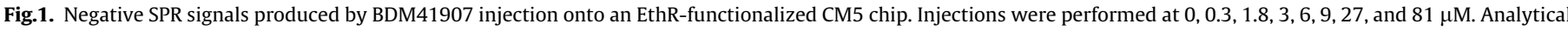

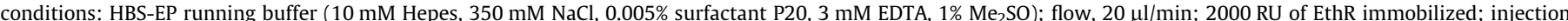

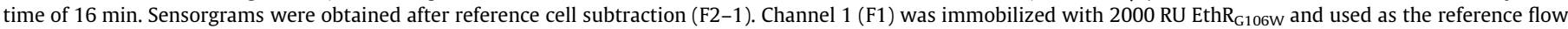
cell. 
the standard protocol provided by BIAcore (GE HealthCare). Injection of $5 \mu \mathrm{l}$ of a $500 \mu \mathrm{M} \mathrm{NiCl}_{2}$ solution was performed to load $\mathrm{Ni}^{2+}$ ions on the surface and activate the NTA sensor chip. Injection of $20 \mu \mathrm{l}$ of a $150 \mathrm{nM}$ solution of EthR in running buffer was performed to achieve a signal of 2700 RU. Eight minutes after EthR immobilization (necessary for baseline stabilization), the ligands were injected over channels F1 and F2 during 4 min so as to observe the equilibrium state. After $10 \mathrm{~min}$ of dissociation, the surface was flushed with $5 \mu \mathrm{l}$ of solution W $(10 \mathrm{mM}$ Hepes, $150 \mathrm{mM} \mathrm{NaCl}$, 0.35 M EDTA, $0.005 \%$ surfactant P20) to remove all protein from the surface. Activation, immobilization, analysis, and regeneration cycle were performed for each ligand analysis. The oriented capture of EthR on the surface of the NTA sensor chip allows slow and continuous dissociation of the protein, resulting in a nonhorizontal baseline. To take this phenomenon into account, subtraction from the same flow cell of a buffer injection completed before ligand analysis was systematically performed. Using this technique, we obtained horizontal baselines that allowed comparison of NTA and CM5 analysis. However, because of this continuous EthR dissociation, NTA sensor chips were not used for $K_{\mathrm{D}}$ determination.

\section{SPR assay for determining the inhibition of EthR/DNA binding by ligands}

Immobilization of biotinylated double-stranded EthA promoter

On sensor chip SA with preimmobilized streptavidin, irrelevant and relevant DNA fragments were immobilized on channels F1 and F2, respectively. The first channel of the chip (F1) was loaded with a $150 \mathrm{ng} / \mathrm{ml}$ biotinylated double-stranded 113-bplong irrelevant DNA fragment at a flow rate of $10 \mu \mathrm{l} / \mathrm{min}$ to obtain $75 \mathrm{RU}$ stable binding to the streptavidin. The 106-bp biotinylated ethA-R DNA intergenic region at $150 \mathrm{ng} / \mathrm{ml}$ was injected through the second channel (F2) at a flow rate of $10 \mu \mathrm{l} / \mathrm{min}$ to reach the same 75-RU stable fixation to the streptavidin. The sensor chip was then washed with $0.03 \%$ SDS before protein injection.
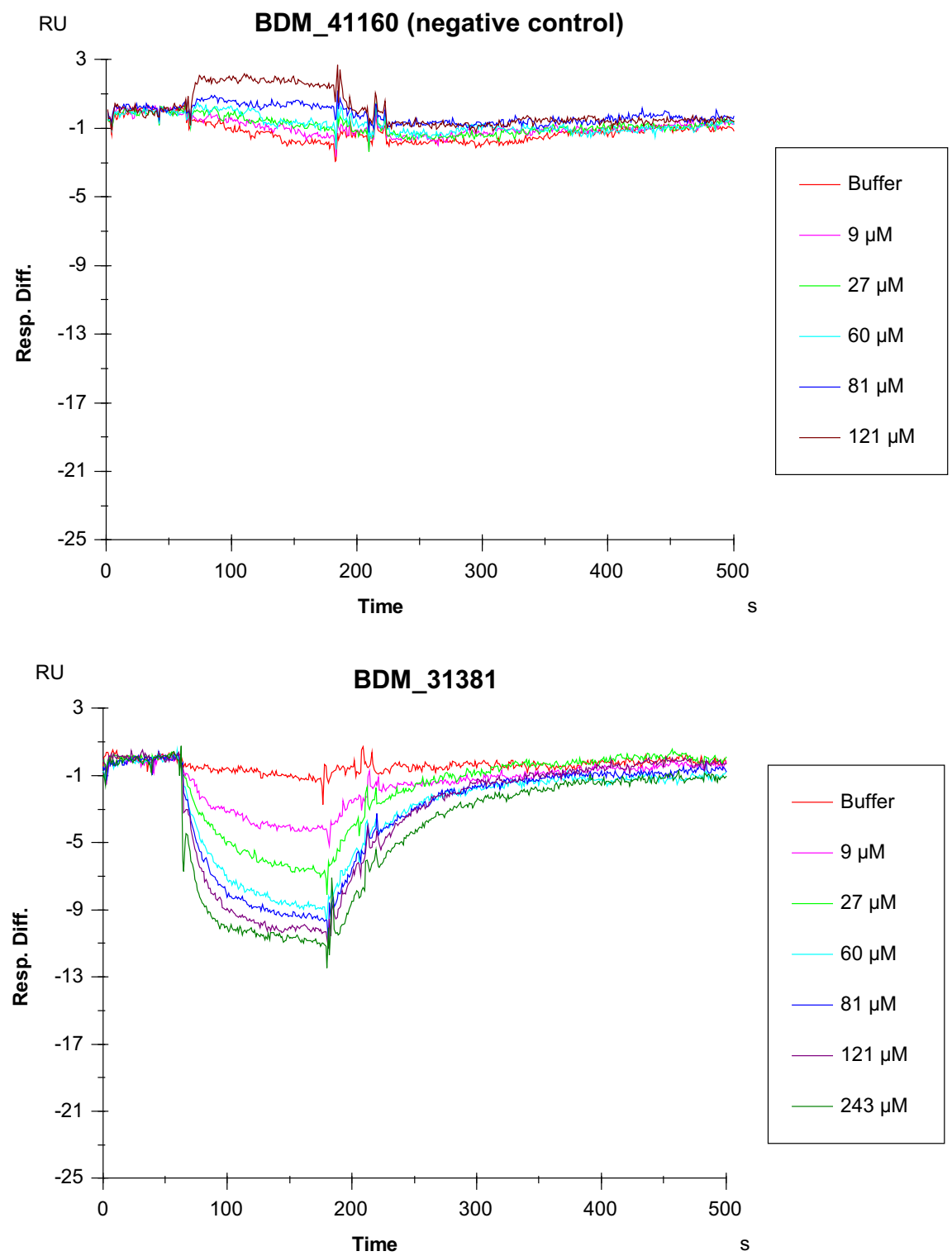

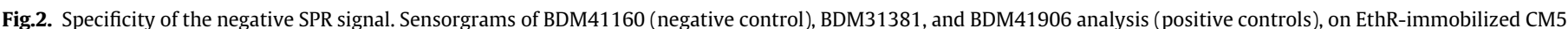

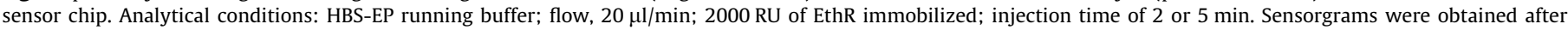
reference cell subtraction (F2-1). Channel 1 (F1) was immobilized with 2000 RU EthR $\mathrm{G}_{\mathrm{G} 106 \mathrm{~W}}$ and used as the reference flow cell. 


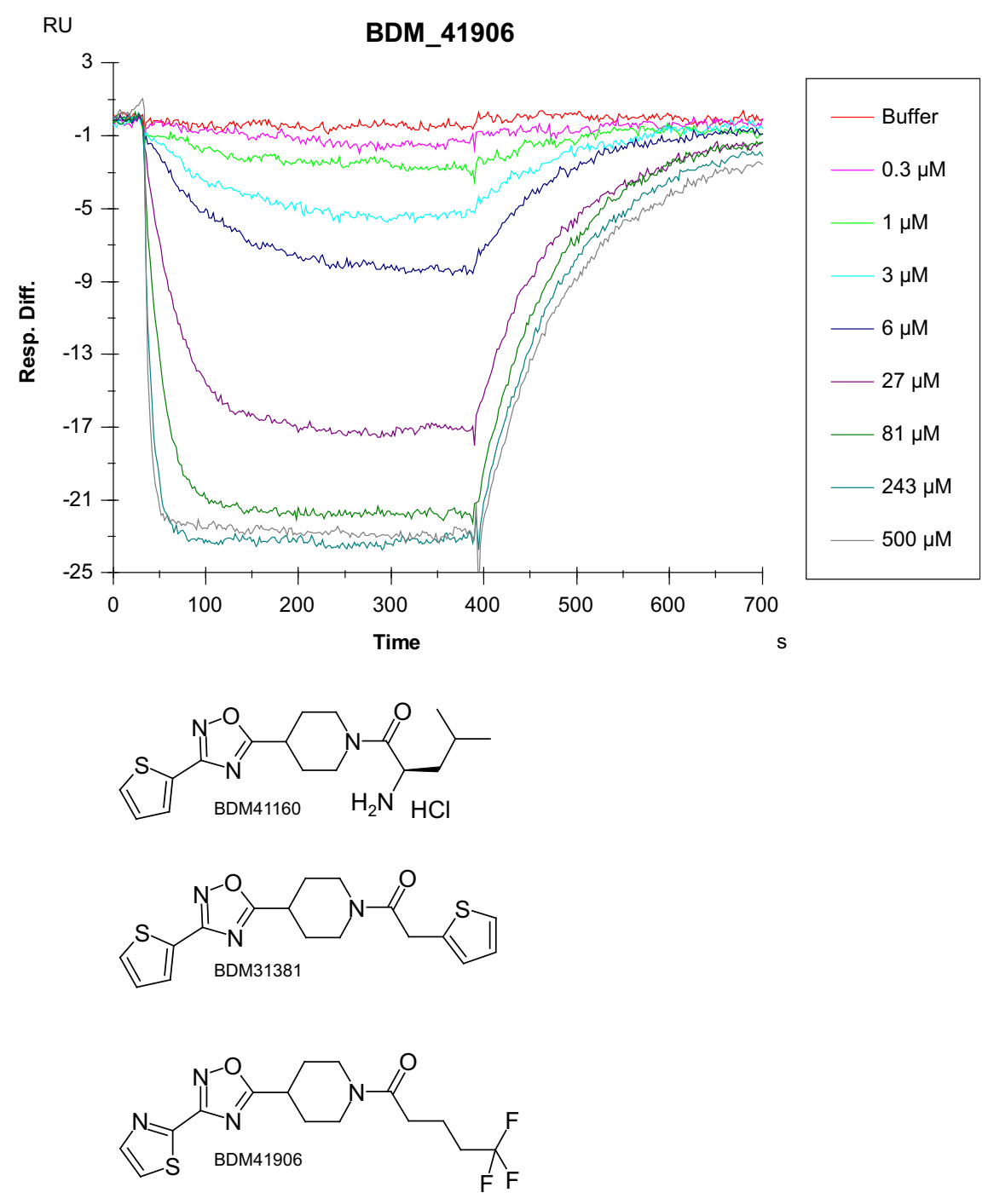

Fig. 2 (continued)

\section{$I C_{50}$ determination}

Binding of EthR to the immobilized DNA was measured at $25^{\circ} \mathrm{C}$ in $10 \mathrm{mM}$ Tris- $\mathrm{HCl}$ (pH 7.5), $200 \mathrm{mM} \mathrm{NaCl}, 0.1 \mathrm{mM}$ EDTA, $1 \mathrm{mM}$ DTT, and $1 \% \mathrm{Me}_{2} \mathrm{SO}$ at a flow rate of $20 \mu \mathrm{l} / \mathrm{min}$. SA sensor chips immobilized with $75 \mathrm{RU}$ of specific and nonspecific DNA fragments were used for the analysis. A specific interaction (SI) between EthR and the 106-bp DNA fragment was defined as the signal difference between both channels (F2-F1). Six different concentrations, between $25.4 \mathrm{nM}$ and $500 \mu \mathrm{M}$, were used for $\mathrm{IC}_{50}$ determination. Successive dilutions of the initial compound solution were performed in the binding buffer to obtain the desired final concentrations containing $1 \%$ in $\mathrm{Me}_{2} \mathrm{SO}$, incubated $5 \mathrm{~min}$ at $37^{\circ} \mathrm{C}$ in the presence of $540 \mathrm{nM}$ EthR, and injected over the two channels at a flow rate of $20 \mu \mathrm{l} / \mathrm{min}$ for $3 \mathrm{~min}$. EthR to DNA dissociation was achieved by flowing buffer for $20 \mathrm{~min}$ on the chip before the next binding measurement. SDS (0.03\%) wash was abolished because of low recovery of stable baseline. SI values were measured at the end of the injection period and allowed to calculate each ligand inhibition percentage according to the following ratio:

$\%$ Inhibition $=100 \times\left[\left(\mathrm{SI}_{\mathrm{EthR}}-\mathrm{SI}_{\mathrm{EthR}+\mathrm{cpd}}\right) / \mathrm{SI}_{\mathrm{EthR}}\right]$.

Percentages of inhibition were plotted as a function of the concentration of the compounds and $\mathrm{IC}_{50}$ values were determined using a sigmoidal dose-response (variable slope) model from GraphPad Prism 5.0. The $\mathrm{IC}_{50}$ is the concentration of inhibitor that causes $50 \%$ inhibition of EthR binding to DNA.

\section{Thermal shift assay}

The thermal shift assay was conducted on a LightCycler 480 system (Roche) in 96-well microplates. To monitor protein unfolding and record the melting temperature of EthR, the protein was heated in the presence of the environmentally sensitive fluorescent dye Sypro orange (Invitrogen). The unfolding process exposes hydrophobic regions of the protein and induces an increase in fluorescence of the dye. To prepare the microplate, $5 \mu \mathrm{l}$ of the ligand at $60 \mu \mathrm{M}$ in Tris buffer ( $50 \mathrm{mM}$ Tris- $\mathrm{HCl}, 300 \mathrm{mM} \mathrm{NaCl}, \mathrm{pH} 7.5$ ) in the presence of $3 \% \mathrm{Me}_{2} \mathrm{SO}$ is introduced into the appropriate wells. The ligand solution is replaced by a $3 \% \mathrm{Me}_{2} \mathrm{SO}$ solution in EthR buffer for the negative controls. The EthR/Sypro orange solution $(10 \mu \mathrm{l})$ is added to all the wells to reach a final concentration of $20 \mu \mathrm{M}$ in ligand, $10 \mu \mathrm{M}$ in EthR, $2.5 \times$ in Sypro orange, and $1 \%$ in $\mathrm{Me}_{2} \mathrm{SO}$. After centrifugation, an incubation time of $30 \mathrm{~min}$ is allowed before the analysis. The plate is heated from 37 to $85^{\circ} \mathrm{C}$ with a heating rate of $0.04{ }^{\circ} \mathrm{C} / \mathrm{s}$. The fluorescence intensity was measured at $465 / 510 \mathrm{~nm}$. The fluorescence imaging data obtained from the LightCycler 480 were treated and analyzed with IGOR software. 


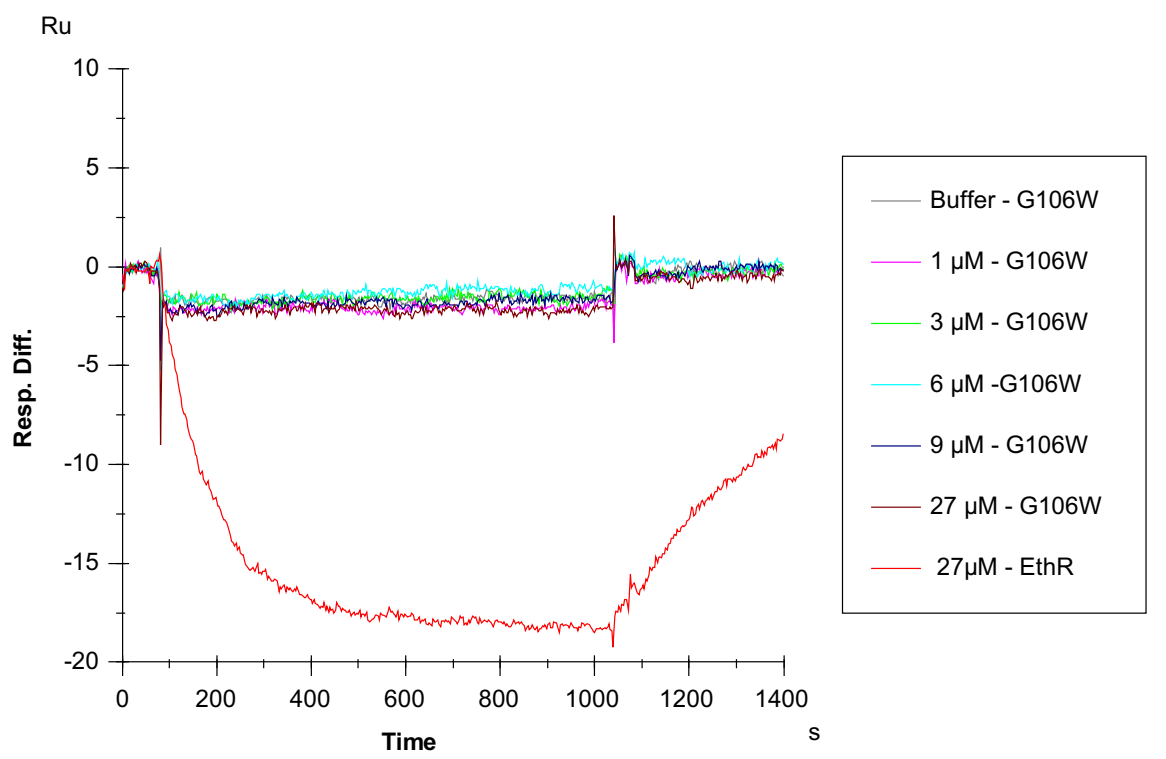

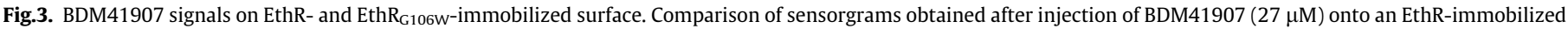

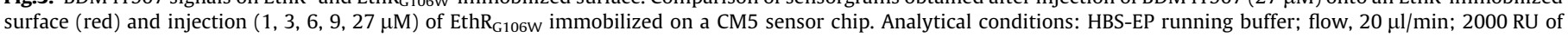

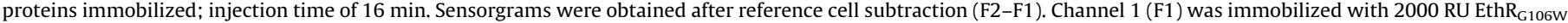
and used as the reference flow cell.

The inflection point of the curves was detected by plotting the first derivative $d \mathrm{FI} / d T$, and the melting temperatures $\left(T_{\mathrm{m}}\right)$ were assessed from the maxima.

\section{Results}

\section{SPR signal of the EthR/ligand interaction}

Developing an SPR assay to detect interactions between small synthetic ligands and EthR on a Biacore 3000 was a real challenge because of the molecular mass of the ligands (between 300 and $500 \mathrm{Da}$ ). According to the $R_{\max }$ formula [14], $2000 \mathrm{RU}$ (2000 pg/ $\mathrm{mm}^{2}$ ) of EthR was covalently immobilized on a CM5 sensor chip. Assuming an expected binding ratio of 1 ligand per EthR monomer, a maximum theoretical response of $28 \mathrm{RU}$ would be expected using a 350-Da ligand. In a first attempt to monitor the ligand-binding propensity of immobilized EthR, we used BDM41907, a ligand known to inhibit with a high efficacy the fixation of the repressor on its DNA operator ( $\left(\mathrm{IC}_{50} 375 \mathrm{nM}\right.$ ). Injected onto the sensor surface functionalized with immobilized EthR, BDM41907 produced an unexpected sensorgram composed exclusively of negative values. However, except for this unanticipated negative profile, the curve showed a classical shape, characterized by a marked and rapid response at the beginning of the injection, followed by a plateau upon continuous injection, and finally the progressive recovering of the initial baseline after injection (Fig. 1).

The SPR signal is specific for the ligand/EthR interaction and dosedependent

Injections with increasing concentrations of BDM41907 from 0.3 to $81 \mu \mathrm{M}$ were tested. Results showed highly reproducible dose-dependent negative responses leading to a bona fide plateau, suggesting that the observed signal, although negative, translates interactions between EthR and BDM41907 (Fig. 1). To assess the specificity of this interaction, we evaluated the capacity of BDM41160, a chemical analogue of BDM41907 previously shown to be inactive as an EthR inhibitor using the TSA or the "DNA-EthR" SPR method [5]. Serial injections of increasing concentrations of
BDM41160 (from 9 to $243 \mu \mathrm{M}$ ) produced no significant positive nor negative shift of the SPR signal (Fig. 2). In contrast, dose-dependent negative SPR signals were again observed with the two other well-characterized specific EthR inhibitors BDM31381 [7] and BDM41906 [6] (Fig. 2).

In a recent work, we designed and characterized a variant of EthR (EthR $\left.R_{\mathrm{G} 106 \mathrm{~W}}\right)$ in which the replacement of glycine 106 by a tryptophan was shown to induce a conformation closely related to the conformations of a holo-protein. X-ray crystallography indeed revealed $E t h R_{\mathrm{G} 106 \mathrm{~W}}$ as an apoprotein stabilized in a liganded-like conformation. SPR experiments confirmed that, despite the absence of ligands bound in its pockets, $\mathrm{EthR}_{\mathrm{G} 106 \mathrm{~W}}$ is unable to bind its DNA operator. Finally, isothermal titration calorimetry experiments confirmed the inability of $\mathrm{EthR}_{\mathrm{G} 106 \mathrm{~W}}$ to interact with synthetic ligands [11], which makes this variant an ideal negative control for the present study. Interestingly, injection of BDM41907 onto a CM5 chip coated with EthR $\mathrm{G}_{\mathrm{G} 106 \mathrm{~W}}$ resulted in a complete absence of SPR signal (Fig. 3).

Altogether, these data strengthened the idea that the SPR dose-dependent negative signal observed with BDM41907 reveals specific interactions with EthR.

Influence of the analytical conditions on the negativity of the SPR signal

To exclude a maximum of possible artifactual effects that could have led to this unusual but specific negative SPR signal [15], we conducted a series of tests, including the variation of the concentration of the immobilized protein, the roles of $\mathrm{Me}_{2} \mathrm{SO}$ and buffer, and the impact of dextran.

In the first set of experiments, the protein density at the surface of the chip was either reduced (1000 RU) or increased $(4000,7000$, $10,000 \mathrm{RU})$ and BDM41907 was injected at the constant value of $9 \mu \mathrm{M}$ (Fig. 4). The negative SPR signal was clearly dependent on the quantity of immobilized protein, suggesting that the negative signal is the consequence of interactions between EthR and ligands.

Deliberate variations in $\mathrm{Me}_{2} \mathrm{SO}$ concentration between running and sample buffers were then tested to evaluate the impact on the 


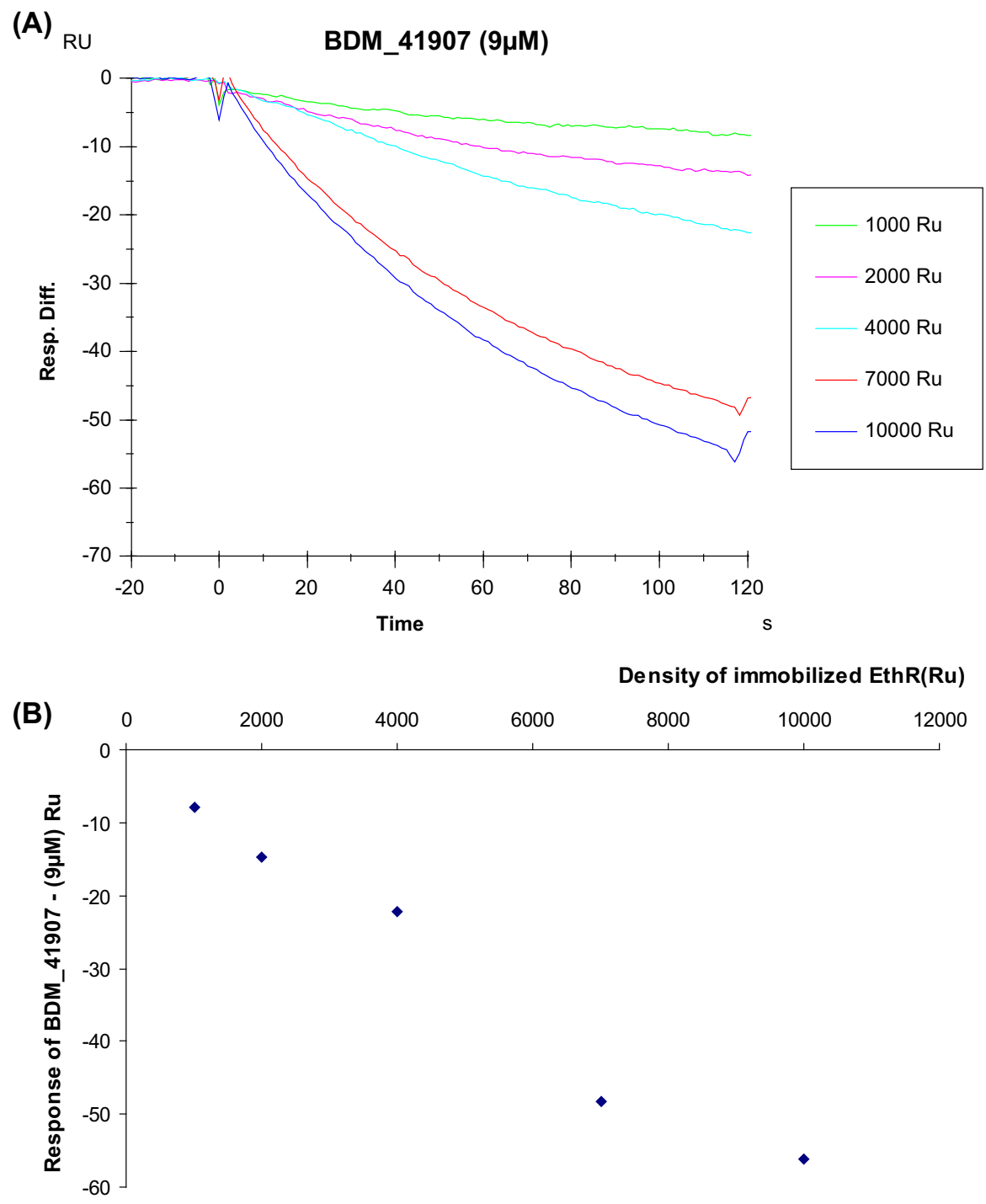

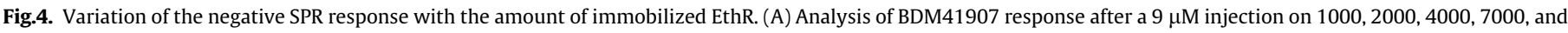

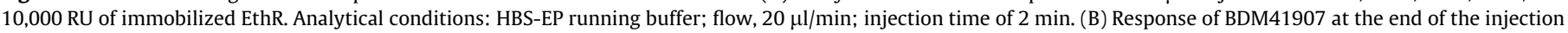
(RU) as a function of the amount of EthR immobilized on the CM5 sensor chip (RU).

refractive index. Injections of buffer were first performed without ligand. The $0.2 \%$ difference in $\mathrm{Me}_{2} \mathrm{SO}$ concentration between the mock sample $(0.8 \%)$ and the running buffer $(1 \%)$ had a visible impact on the sensorgram (Fig. 5A). However, the correction using reference subtraction (F2-F1) drastically reduced this effect from 200 to $4 \mathrm{RU}$ (Fig. 5B). Subsequently, solutions of BDM41907 in which $\mathrm{Me}_{2} \mathrm{SO}$ concentration ranged from $0.8 \%$ to $1.2 \%$ were prepared. These samples were injected on the EthR-bound chips flowed in a running buffer containing $1 \% \mathrm{Me}_{2} \mathrm{SO}$. Classical reference subtraction applied to the various BDM41907 injections almost completely eliminated differences in the response level. Moreover, reproducible signals of the $9 \mu \mathrm{M}$ ligand injections were obtained despite various differences between the $\mathrm{Me}_{2} \mathrm{SO}$ concentrations in the running buffer versus in the sample buffer (Fig. 5C).

It has been shown that variations in $\mathrm{Me}_{2} \mathrm{SO}$ concentration can occasionally give rise to large and rapid shifts in refractive index during injection and thus can induce analytical artifacts [16]. Our results revealed no such injection artifacts, suggesting that the negative signal observed upon interaction between EthR and its ligands cannot be attributed to the slight variations in $\mathrm{Me}_{2} \mathrm{SO}$ concentration that may occur in the experiment.
To fully rule out any possible influence of the $\mathrm{Me}_{2} \mathrm{SO}$ in the recorded negative signal, we used BDM41906, which shows a solubility higher than $1 \mathrm{mM}$ in phosphate-buffered saline, to perform the experiment in the absence of $\mathrm{Me}_{2} \mathrm{SO}$. BDM41906 as a powder was solubilized at $100 \mu \mathrm{M}$ directly in HBS-EP buffer (HBS-EP-no $\mathrm{Me}_{2} \mathrm{SO}$ ) (10 mM Hepes, $150 \mathrm{mM} \mathrm{NaCl}, 0.005 \%$ surfactant P20, $3 \mathrm{mM}$ EDTA). The binding experiment between BDM41906 and EthR was performed on a CM5 sensor functionalized with 4000 $\mathrm{RU}$ of EthR $\mathrm{G}_{\mathrm{G} 106 \mathrm{~W}}$ on the reference flow cell (F1) and with the equivalent amount of EthR on the analysis flow cell (F2) in the presence of the HBS-EP-no $\mathrm{Me}_{2} \mathrm{SO}$ running buffer. BDM41906 was injected at concentrations ranging from 0.3 to $100 \mu \mathrm{M}$ on both channels. As shown in Fig. 5D, a negative, dose-dependent signal was recorded upon injection of the $\mathrm{Me}_{2} \mathrm{SO}$-free BDM41906 solution, showing that the unconventional signal observed in our previous experiments is unrelated to the presence of $\mathrm{Me}_{2} \mathrm{SO}$.

It has been reported by some authors that a progressive loss of matter during the run may sometimes result in a decrease in the refractive index. Thus, we investigated the possibility that interaction of EthR and dextran on the chip could decrease upon ligand binding, which would take the protein away from the sensor chip 
and explain the negative SPR signal. To challenge this hypothesis, we first analyzed a possible competition between free and immobilized dextran. Injections of free dextran on the EthR sensor surface were performed and no variation of the signal was recorded. Then, we showed that injection of free dextran at various concentrations $(0.1,1$, and $5 \mathrm{mg} / \mathrm{ml})$ did not modify the binding signal observed with BDM41907. Altogether, these data showed that dextran has no significant affinity for EthR, excluding its capacity to bring the immobilized protein closer to the chip by interacting with it (see sensorgrams in the Supplementary material).

Alternatively, one can hypothesize the putative displacement from the chip of a component other than EthR. As the SPR signal returns to the initial value after injection phase, this would imply that such loss would be systematically replaced by a component present in the running buffer. To test this hypothesis, we replaced the initial HBS-EP buffer (used for the continuous flow and for the sample preparation) by Tris buffer. Under these new conditions, the previously observed negative signal was again obtained, thus definitely ruling out the hypothesis of matter displacement.

In addition, the putative influence of electrostatic effect was evaluated by testing a range of $\mathrm{NaCl}$ concentrations. Variation of the SPR signal induced by the interactions of EthR and inhibitors was not dependent on salt concentration in the tested range of $150-550 \mathrm{mM} \mathrm{NaCl}$.

We finally tested whether this unconventional SPR signal can be observed independent of the nature of the physicochemical link that attaches EthR onto the chip. In the experiments described so far, EthR had been covalently immobilized to CM5 sensor chips. In this context, EthR was attached to the carboxymethylated dextran matrix using the amine coupling chemical procedure described under Materials and methods. We then tested whether coupling EthR to the sensor chip using a noncovalent capture method would still give negative SPR signal upon ligand binding

(A)

RU Buffer injection (F2)

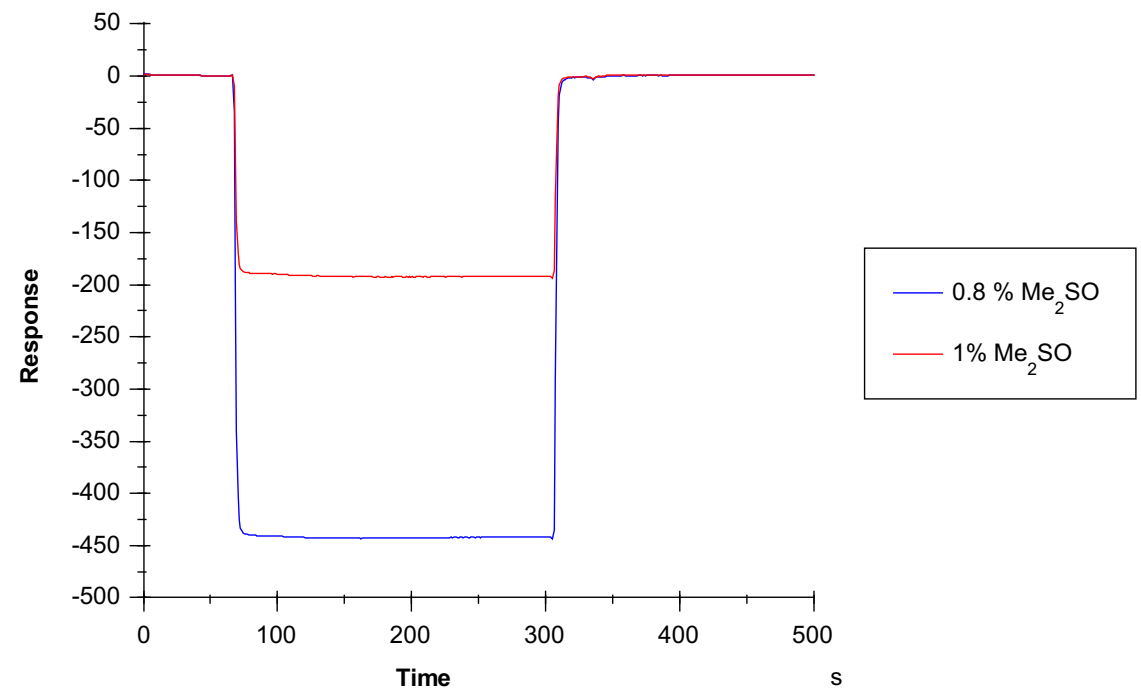

(B) $\mathrm{RU}$

Buffer injection (F2-F1)

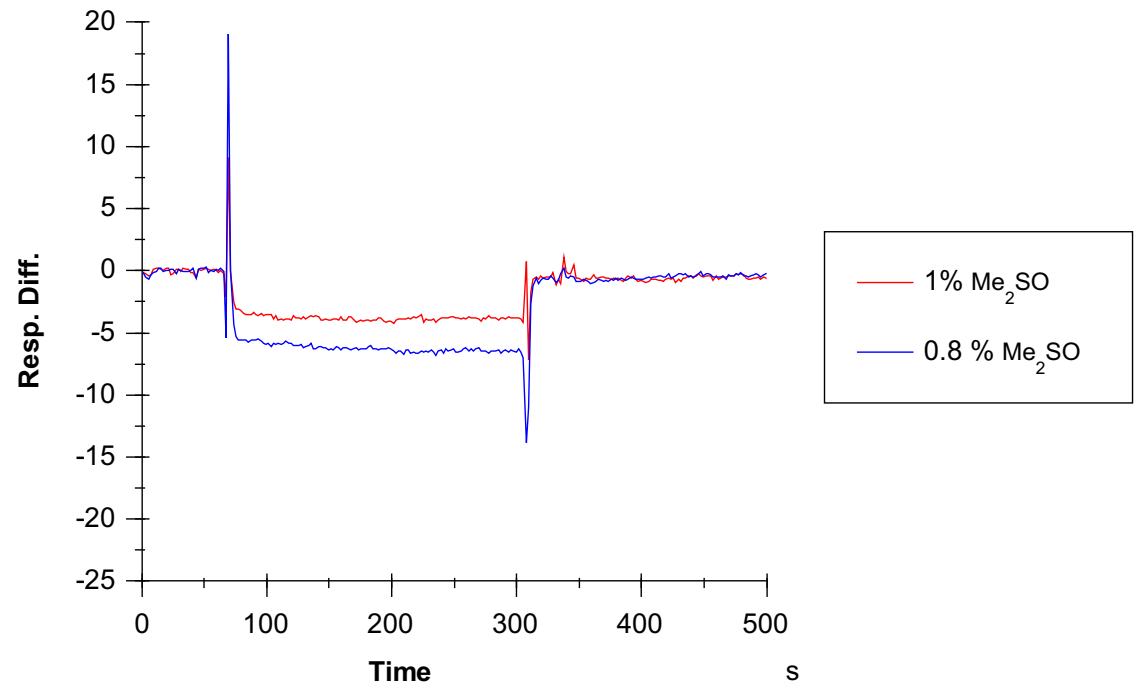

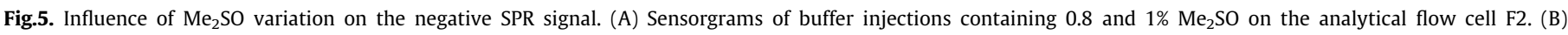

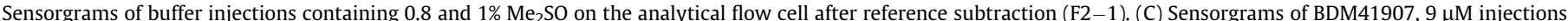

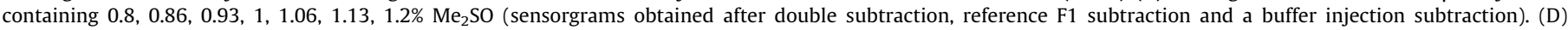
Sensorgrams of various concentrations of BDM41906 in $\mathrm{Me}_{2}$ SO-free buffer (10 mM Hepes, $150 \mathrm{mM} \mathrm{NaCl}, 0.005 \%$ surfactant P20, 3 mM EDTA) (F2-1). 
(C) $\mathrm{RU}$

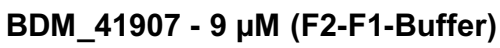

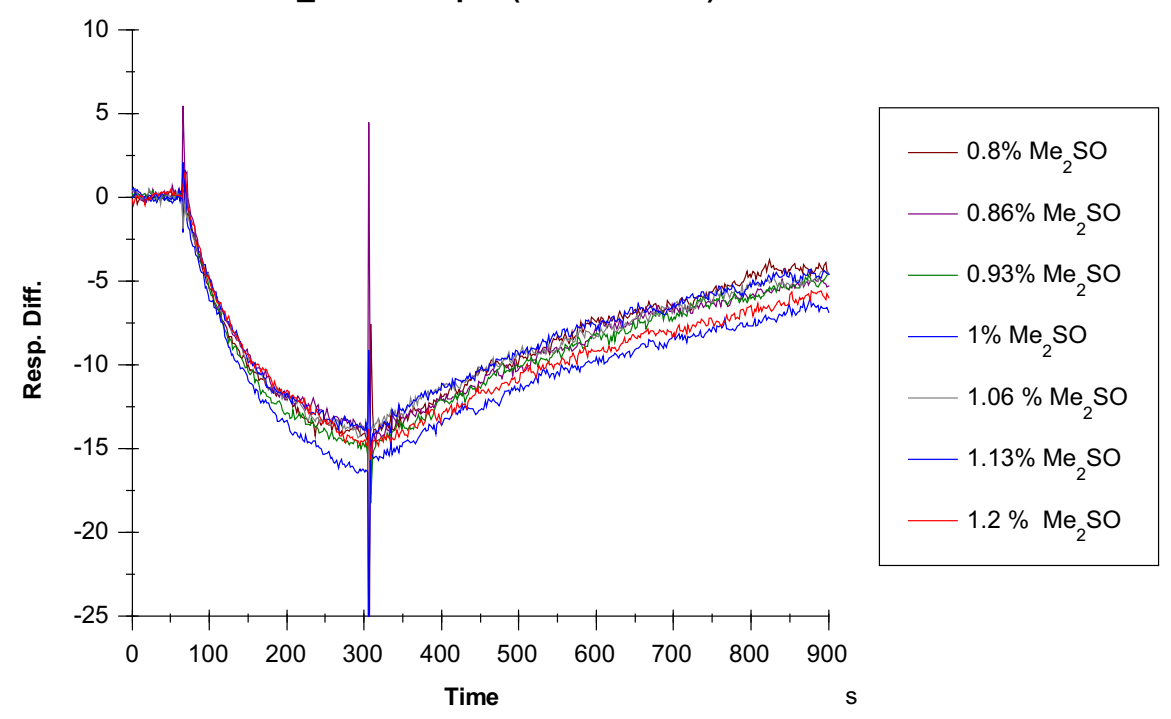

(D)

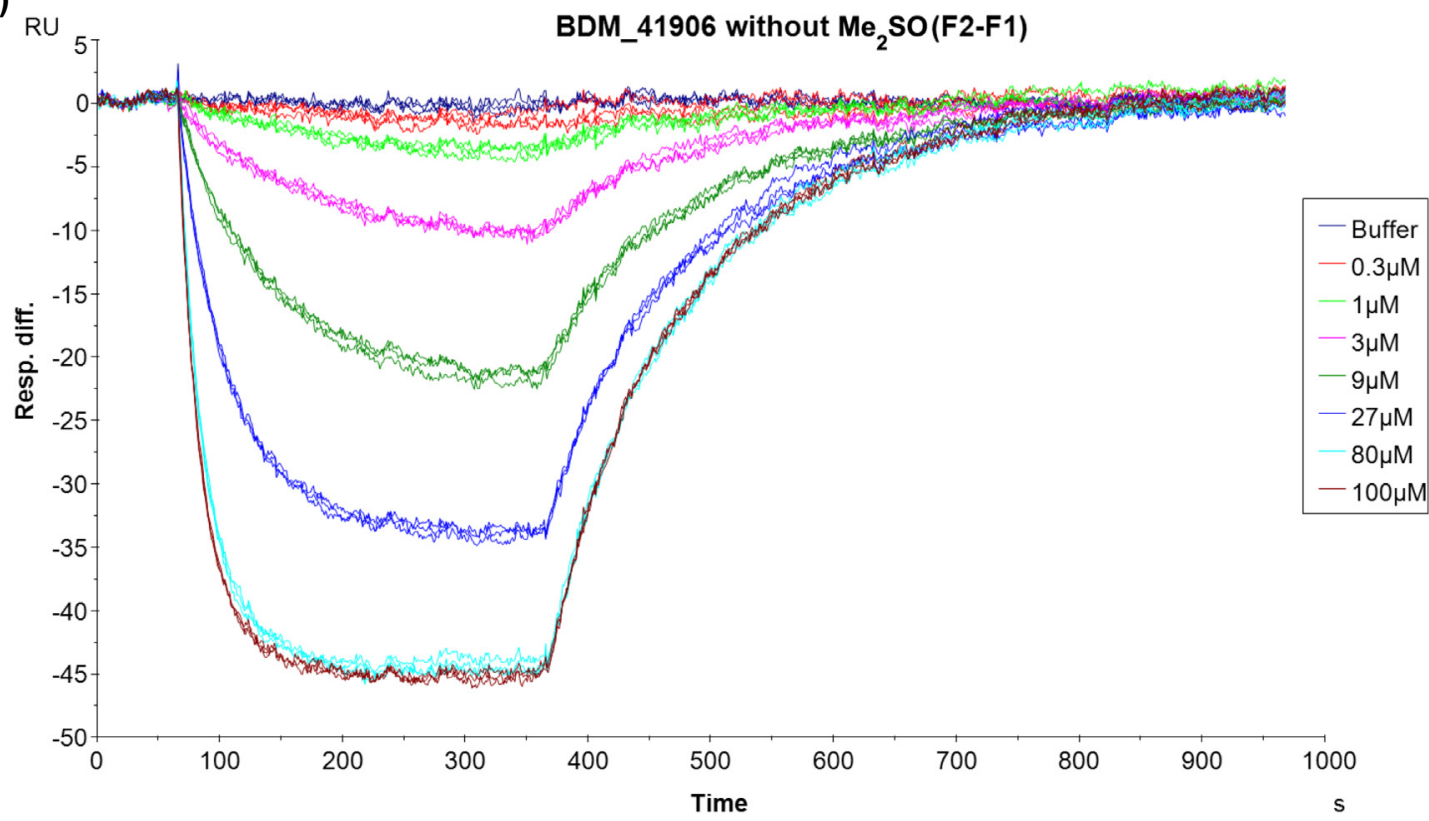

Fig. 5 (continued)

to the protein. To this purpose, His-tagged EthR was captured in the presence of $\mathrm{Ni}^{2+}$ ions on carboxymethylated dextran matrix containing immobilized NTA (see Materials and methods). As previously shown for EthR-coated CM5 chips, injections of BDM41907 on NTA chips coated with His-tagged EthR produced a concentration dependent negative variation of the signal associated with an equilibrium state (Fig. 7).

\section{Dissociation constant determination}

Whereas the physicochemical mechanisms withstanding the negative SPR signal remain to be elucidated, this signal was shown to be ligand-specific and dose-dependent. Other authors previously used such unconventional negative SPR curves to calculate the protein-ligand dissociation constant [17-20]. We applied this methodology to measure the dissociation constant values of a set of well-characterized EthR ligands. In our experiments, the SPR signal recorded on EthR was systematically subtracted from the signal

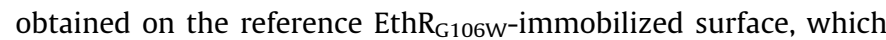
drastically reduced all major injection artifacts. Association and dissociation curves obtained after inversion of the negative sensorgrams were fitted using a kinetic Langmuir model 1:1 and led to an acceptable fit residue and $\chi^{2}$ parameters (inferior to $5 \%$ of the $R_{\max }$ ) (Fig. 6). The kinetic parameters were independent of the flow rate, indicating that the binding interaction between inhibitors and EthR was not limited by a mass transport effect. $K_{\mathrm{D}}$ values corresponding to the association and dissociation curves obtained are presented in Table 1 . Moreover, no significant variations in $K_{\mathrm{D}}$ values were observed using various densities of protein captured on the sensor chip (1000, 2000, and $4000 \mathrm{RU}$, Table 2). $K_{\mathrm{D}}$ values obtained from the fitting procedure using the $1: 1$ binding Langmuir model were compared with $K_{\mathrm{D}}$ extrapolated from measures of the resonance unit at the equilibrium state as a function of the ligand concentration ( $K_{\mathrm{D}}$ at equilibrium, Table 2 ). Both methods reported equivalent values, confirming the validity of the fitting model chosen for $K_{\mathrm{D}}$ determination. 
(A)

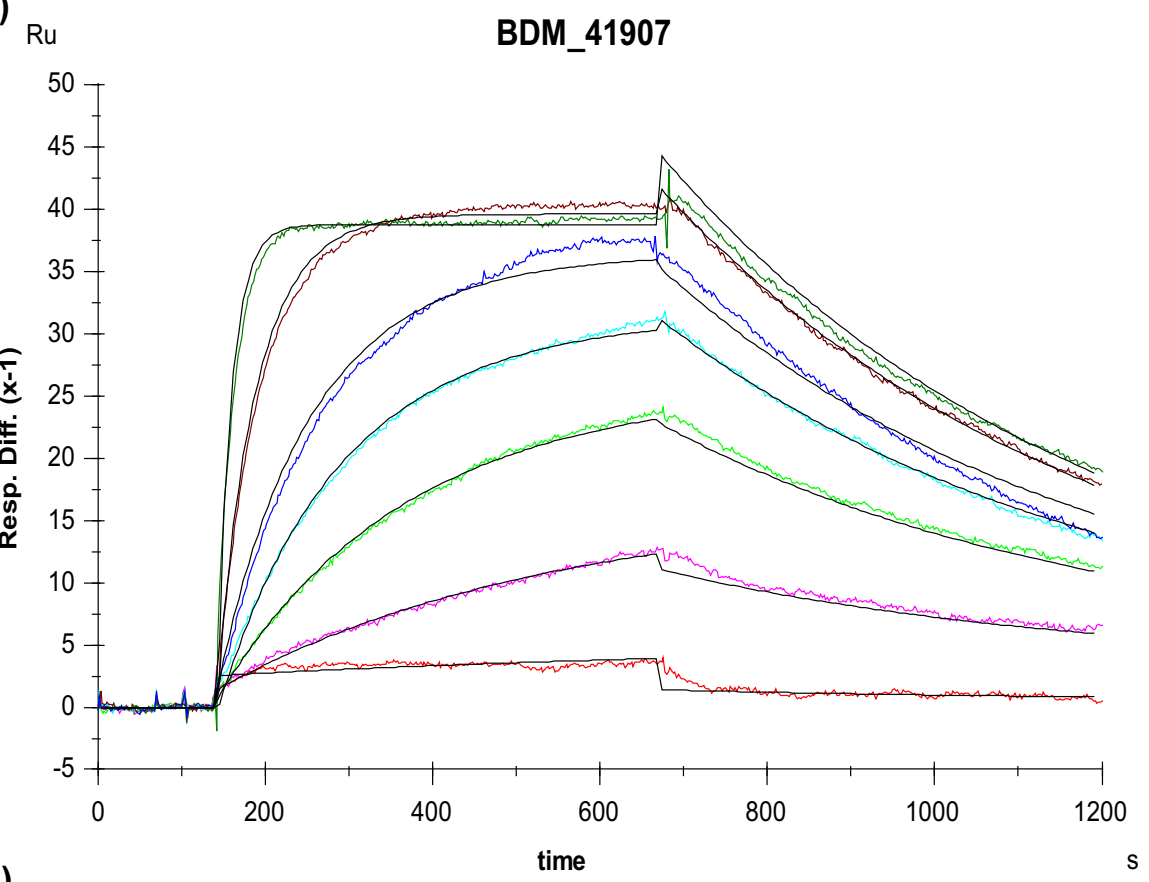

(B)

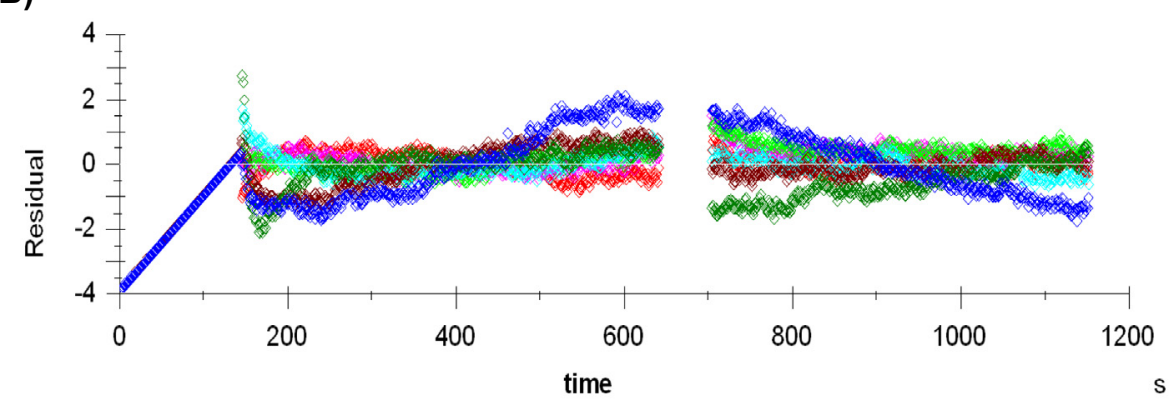

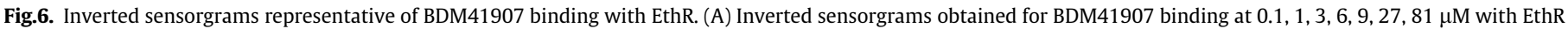

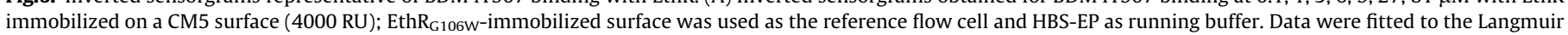
$1: 1$ interaction model. (B) Plot of the residuals (differences between the data and the fit).

Comparison of affinity data obtained by SPR and additional biological parameters used to study EthR/ligand interaction $\left(T_{m}, I C_{50}\right)$

In previous studies, we have described various methods that inform us directly or indirectly on the capacity of compounds to bind to EthR. The first developed method was a TSA revealing the capacity of compounds to thermostabilize EthR upon binding $[8,11,21]$. A positive shift $\left(\Delta T_{\mathrm{m}}\right)$ in the melting temperature of the repressor EthR in the presence of an inhibitor, relative to the $T_{\mathrm{m}}$ of the unbound protein, indicates that stabilization of the protein by the compound has occurred. Independent studies have shown that the stabilization of the protein due to ligand binding as revealed by TSA is proportional to the affinity and the concentration of the ligand [22]. The $K_{\mathrm{D}}$ 's deduced from the dose-dependent negative SPR signal for 13 synthetic ligands were compared with $\Delta T_{\mathrm{m}}$ values obtained by TSA. Results presented in Table 3 show a good correlation with an $R^{2}$ of 0.84 .

In parallel to the TSA, we previously designed a low-throughput SPR test that measures the capacity of synthetic compounds to impede the binding of EthR to its DNA operator [5-7]. Our effective EthR inhibitors revealed typical $\mathrm{IC}_{50}$ in the micro- to the nanomolar range. In Table 3, for 10 different ligands, we compared $\mathrm{p} K_{\mathrm{D}}$ obtained by the ligand/EthR SPR test and $\mathrm{PIC}_{50}$ values deduced from the EthR/DNA SPR test. The obtained correlation factor $R^{2}$ of 0.81 indicates that the affinity of the ligands for EthR is correlated with their ability to inhibit the DNA-binding function of EthR.

\section{Discussion}

The pivotal second-line anti-tuberculosis drug ethionamide undergoes a process of bioactivation by the monooxygenase EthA [4], the expression of which is negatively regulated by the TetR-like repressor EthR in $M$. tuberculosis. It was demonstrated that the basal level of EthR limits the bioactivation of ethionamide and, consequently, participates in an innate form of resistance of $M$. tuberculosis to this antibiotic. Previous works identified small molecules that inhibit EthR and thus increase ethionamide efficacy $[5-8,10]$.

In these previous studies we developed several biological and biophysical assays to establish strong structure-activity relationships. SPR was used to reveal the capacity of compounds to inhibit EthR/DNA interaction in vitro [5-7]. It appeared reasonably predictive of the efficacy of the compounds in vivo. However, the DNA/ EthR SPR methodology reflects globally only the equilibrium that encompasses both the binding of ligand to EthR and the binding of EthR to its DNA operator. Although a thermal shift assay was developed to quantify the thermostabilization of EthR by small synthetic ligands $[8,11]$, this test did not allow one to determine 

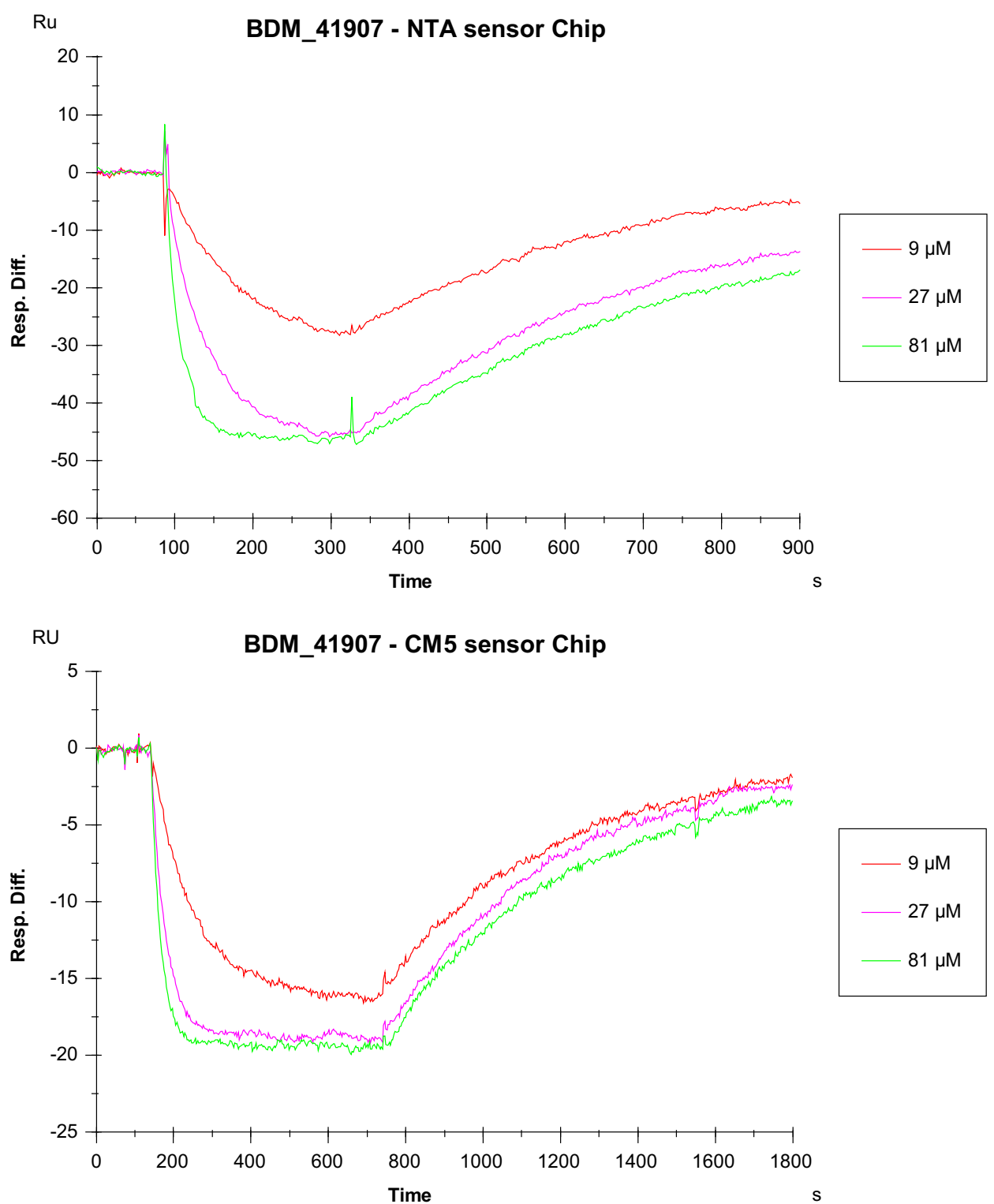

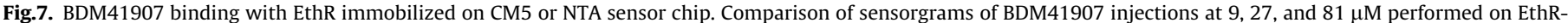
immobilized (2700 RU) NTA sensor chip and EthR-immobilized (2000 RU) CM5 sensor chip.

Table 1

Dissociation constants of EthR/ligand interactions measured by SPR.

\begin{tabular}{|c|c|c|c|c|c|}
\hline Ligand & $10^{-2} k_{\text {on }}\left(\mathrm{M}^{-1} \mathrm{~s}^{-1}\right)$ & $10^{2} k_{\text {off }}\left(\mathrm{s}^{-1}\right)$ & $R_{\max }(\mathrm{RU})$ & $10^{6} K_{\mathrm{D}}^{\mathrm{a}}(\mathrm{M})$ & $\chi^{2}$ \\
\hline BDM44829 & 31.4 & 0.33 & 18.7 & 1.07 & 0.432 \\
\hline BDM44831 & 8.16 & 0.12 & 17.4 & 1.53 & 0.422 \\
\hline BDM41907 & 7.83 & 0.16 & 44.1 & 2.00 & 0.503 \\
\hline BDM43266 & 13.5 & 0.82 & 33.1 & 6.10 & 0.577 \\
\hline BDM41956 & 21.2 & 2.31 & 27.6 & 10.9 & 0.518 \\
\hline BDM41906 & 6.77 & 0.99 & 37.6 & 14.8 & 0.162 \\
\hline BDM44699 & 29.8 & 4.80 & 28.4 & 16.3 & 0.775 \\
\hline BDM31381 & 7.71 & 2.11 & 23.4 & 27.4 & 0.262 \\
\hline BDM31377 & 5.40 & 1.80 & 9.9 & 33.3 & 0.196 \\
\hline BDM41281 & 4.16 & 2.76 & 26.9 & 66.3 & 0.477 \\
\hline BDM41329 & 39.6 & 28.2 & 10.3 & 71.3 & 0.080 \\
\hline BDM41955 & 5.84 & 6.80 & 25.6 & 117 & 0.213 \\
\hline BDM31379 & 6.54 & 9.05 & 6.3 & 138 & 0.106 \\
\hline
\end{tabular}

a Dissociation constants were measured on a CM5 sensor chip immobilized with $4000 \mathrm{RU}$ of EthR. Sensorgrams were obtained after injection of at least six concentrations

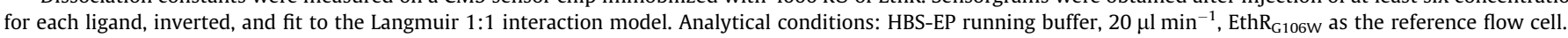

binding constants. Albeit highly informative of the indirect activity of the compounds at the various biological levels of the cell, all these tests were unsuitable for ranking compounds strictly based on their affinity for the target. 
Table 2

Comparison of $K_{\mathrm{D}}$ measured by SPR.

\begin{tabular}{llll}
\hline & BDM41907 & BDM41906 & BDM31381 \\
\hline $\mathbf{1 0}^{\mathbf{6}} \boldsymbol{K}_{\mathbf{D}}$ eq (M) (2000 RU) & $\mathbf{1 . 7 0}$ & $\mathbf{1 5 . 0}$ & $\mathbf{2 4 . 0}$ \\
$10^{6} K_{\mathrm{D}}$ fit (M) (1000 RU) & 1.65 & 15.3 & 27.8 \\
$\mathbf{1 0}^{\mathbf{6}} \boldsymbol{K}_{\mathbf{D}}$ fit (M) (2000 RU) & $\mathbf{1 . 7 0}$ & $\mathbf{1 6 . 0}$ & $\mathbf{2 2 . 4}$ \\
$10^{6} K_{\mathrm{D}}$ fit (M) (4000 RU) & 2.00 & 14.8 & 27.4 \\
Repeatability ( $\times 5) 10^{6} K_{D}(M)$ & $1.58 \pm 0.29$ & $13.0 \pm 2.1$ & $25.8 \pm 2.6$ \\
$10^{3} k_{\text {off }}$ fit (M) (1000 RU) & 2.02 & 10.7 & 23.0 \\
$10^{3} k_{\text {off }}$ fit (M) (2000 RU) & 2.01 & 9.22 & 13 \\
$10^{3} k_{\text {off }}$ fit (M) (4000 RU) & 1.61 & 9.99 & 21.1 \\
\hline
\end{tabular}

$K_{\mathrm{D}}$ and $k_{\mathrm{d}}$ values for BDM41907, BDM41906, and BDM31381 using 1000, 2000, or $4000 \mathrm{RU}$ of captured EthR are shown in regular font. Comparisons of fitting and equilibrium processes for $K_{\mathrm{D}}$ determination by SPR are shown in boldface.

Table 3

Comparison of the biological assays performed on EthR inhibitors.

\begin{tabular}{lllc}
\hline Ligand & $\mathrm{p} K_{\mathrm{D}}$ & $\Delta T_{\mathrm{m}}\left({ }^{\circ} \mathrm{C}\right)^{\mathrm{a}}$ & $\mathrm{pIC}_{50}{ }^{\mathrm{b}}$ \\
\hline BDM44829 & 5.97 & 13.0 & $-{ }^{\mathrm{c}}$ \\
BDM44831 & 5.81 & 12.6 & 6.3 \\
BDM41907 & 5.69 & 11.0 & 6.5 \\
BDM43266 & 5.21 & 11.3 & 6.4 \\
BDM41956 & 4.96 & 8.5 & 6.3 \\
BDM41906 & 4.82 & 9.5 & 6.4 \\
BDM44699 & 4.78 & 8.0 & $-{ }^{\mathrm{c}}$ \\
BDM31381 & 4.56 & 9.8 & 5.8 \\
BDM31377 & 4.47 & 9.0 & 5.8 \\
BDM41281 & 4.17 & 8.5 & 5.7 \\
BDM41329 & 4.14 & 6.0 & 5.3 \\
BDM41955 & 3.93 & 6.3 & $-{ }^{\mathrm{c}}$ \\
BDM31379 & 3.86 & 6.6 & 5.2 \\
Correlation factor $R^{2}$ & & 0.8411 & 0.8087
\end{tabular}

a $\Delta T_{\mathrm{m}}$ represents the variation in the melting temperature of the repressor EthR in the presence of inhibitor, relative to the $T_{\mathrm{m}}$ of the unbound protein alone.

${ }^{b} \mathrm{IC}_{50}$ represents the concentration of ligand that inhibits $50 \%$ of the interaction of EthR with its promoter.

c No value because of solubility problems.

To overcome this limitation, we therefore developed a new SPR assay based on the immobilization of the transcriptional repressor on a CM5 sensor chip to determine $K_{\mathrm{D}}$ values with our inhibitors. All 13 tested compounds injected onto the EthR-coated chip produced unexpected SPR profiles characterized by negative values. No signal was recorded when inactive analogues were tested, nor when known EthR inhibitors were injected onto a chip functionalized with an EthR variant harboring a mutation known to block the entrance of ligand into the binding pocket.

The $K_{\mathrm{D}}$ values deduced from the dose-response curves obtained with the studied ligands were compared with activities deduced using two other assays. $K_{\mathrm{D}}$ 's appear nicely correlated with $\Delta T_{\mathrm{m}}$ values obtained from thermal shift assays $\left(R^{2}=0.84\right)$, as well as with $\mathrm{IC}_{50}$ values measured using an EthR/DNA SPR assay $\left(R^{2}=0.81\right)$. Two conclusions emerge from these results. First, the relatively solid correlation emerging from these pairwise comparisons reinforces the evidence that the negative SPR signal recorded reflects specific and quantitative affinity between EthR and ligands. Second, an important question concerning the inhibition of the DNA-binding properties of EthR was about the relationship between the affinity of ligands for EthR and their effect on the DNA binding. With the actual assay, we have now demonstrated that the inhibition of the DNA-binding function of EthR $\left(\mathrm{IC}_{50}\right)$ by synthetic inhibitors is directly correlated with their affinity $\left(K_{\mathrm{D}}\right)$ for EthR.

SPR techniques have been extensively used to detect interactions between two biological objects [12], assuming that the detected effect is due to refractive index changes mainly due to mass changes. Nevertheless, a growing number of teams have reported negative dose-dependent SPR signals [17-20] tentatively attributed to structural changes in the receptor induced by small ligands or inhibitors. Our results revealed a good correlation between the observed negative, dose-dependent, SPR signal and the binding of our ligands to EthR.

In this work, we have tempted to identify what could explain such negative SPR signal. The influence of buffers, $\mathrm{Me}_{2} \mathrm{SO}$, protein concentrations, and electrostatic parameters has been carefully examined and eventually ruled out, opening the hypothesis that the observed negative signal may reflect the structural changes resulting from the ligand/protein interaction. The structural changes in EthR and other TetR-type regulators mainly involve the two helix-turn-helix (HTH) motifs of the dimeric active protein [23-27]. Here, we propose that the negative SPR signal recorded for EthR upon ligand binding may be detected using a nonoriented functionalization of EthR to the biosensor. Changes in protein conformation upon ligand binding do not systematically translate in negative SPR signal [28]. One can imagine that a positive signal can also result from such changes, but this signal would be masked by what would be assigned to the change of mass on the chip. Various teams have observed equivalent negative SPR responses upon protein/ligand interactions [17-20]. Although not yet fully characterized and still under debate, this signal was hypothesized to reflect major changes in protein conformation resulting from ligand binding [18]. Crystallographic studies revealed that EthR is composed of two symmetrical ligand-binding sites and two mobile HTH motifs. These motifs are submitted to major structural reorganization upon ligand binding: whereas DNA architecture forces HTH motifs to adopt approximately a $34-\AA ̊$ center-to-center distance, the structure of the liganded form of EthR revealed a $52-\AA$ center-to-center distance. Thus, the main structural modification endured by the protein upon ligand binding is of large amplitude (more than $15 \AA$ ), highly polarized, and peripheral [23-27].

While the impact of the amplitude of the conformational change in SPR signal is not easily measurable or predictable, the detection of conformational changes by SPR could constitute an unexpected powerful functional screening method for the identification of allosteric inhibitors. In radioactive binding assays, for instance, small ligands that interact with the target are identified regardless of their capacity to induce conformation changes. In contrast, the negative SPR signal observed here informed us on both the binding constants and the inhibitory activity of EthR synthetic ligands, which opens new perspectives on the use of SPR to identify inhibitors of transcriptional regulators or of any liganddependent allosteric control of soluble proteins.

\section{Acknowledgments}

We thank the Institute of Predictive Medicine and Therapeutic Research, IFR 114, for technical support. This work was supported by INSERM, the University of Lille Nord de France, Institut Pasteur de Lille, CNRS, European Union, Région Nord-Pas de Calais, FEDER (Nos. 09220019 and 09220020 PRESAGE 31510), ANR (ANR-06EMPB-033), and PRIM: Pôle de Recherche Interdisciplinaire du Médicament (Projet Phare CPER TB DRUG BOOST Grant 11002859).

\section{Appendix A. Supplementary data}

Supplementary data associated with this article can be found, in the online version, at http://dx.doi.org/10.1016/j.ab.2014.02.011.

\section{References}

[1] Global Tuberculosis Report 2013, WHO, Geneva, 2013.

[2] J. Engohang-Ndong, D. Baillat, M. Aumercier, F. Bellefontaine, G.S. Besra, C. Locht, A.R. Baulard, EthR, a repressor of the TetR/CamR family implicated in ethionamide resistance in mycobacteria, octamerizes cooperatively on its operator, Mol. Microbiol. 51 (2004) 175-188. 
[3] M.W. Fraaije, N.M. Kamerbeek, A.J. Heidekamp, R. Fortin, D.B. Janssen, The prodrug activator EtaA from Mycobacterium tuberculosis is a Baeyer-Villiger monooxygenase, J. Biol. Chem. 279 (2004) 3354-3360.

[4] T.A. Vannelli, A. Dykman, P.R. Ortiz de Montellano, The antituberculosis drug ethionamide is activated by a flavoprotein monooxygenase, J. Biol. Chem. 277 (2002) 12824-12829.

[5] M. Flipo, M. Desroses, N. Lecat-Guillet, B. Dirié, X. Carette, F. Leroux, C. Piveteau, F. Demirkaya, Z. Lens, P. Rucktooa, V. Villeret, T. Christophe, H.K. Jeon, C. Locht, P. Brodin, B. Déprez, A.R. Baulard, N. Willand, Ethionamide boosters: synthesis, biological activity, and structure-activity relationships of a series of 1,2,4-oxadiazole EthR inhibitors, J. Med. Chem. 54 (2011) 2994-3010.

[6] M. Flipo, M. Desroses, N. Lecat-Guillet, B. Villemagne, N. Blondiaux, F. Leroux, C. Piveteau, V. Mathys, M.P. Flament, J. Siepmann, V. Villeret, A. Wohlkönig, R. Wintjens, S.H. Soror, T. Christophe, H.K. Jeon, C. Locht, P. Brodin, B. Déprez, A.R. Baulard, N. Willand, Ethionamide boosters 2. Combining bioisosteric replacement and structure-based drug design to solve pharmacokinetic issues in a series of potent 1,2,4-oxadiazole EthR inhibitors, J. Med. Chem. 55 (2012) 68-83.

[7] N. Willand, B. Dirié, X Carette, P. Bifani, A Singhal, M. Desroses, F. Leroux, E Willery, V. Mathys, R. Déprez-Poulain, G. Delcroix, F. Frénois, M. Aumercier, C. Locht, V. Villeret, B. Déprez, A.R. Baulard, Synthetic EthR inhibitors boost antituberculous activity of ethionamide, Nat. Med. 15 (2009) 537-544.

[8] M. Flipo, N. Willand, N. Lecat-Guillet, C. Hounsou, M. Desroses, F. Leroux, Z. Lens, V. Villeret, A. Wohlkönig, R. Wintjens, T. Christophe, H. Kyoung Jeon, C. Locht, P. Brodin, A.R. Baulard, B. Déprez, Discovery of novel Nphenylphenoxyacetamide derivatives as EthR inhibitors and ethionamide boosters by combining high-throughput screening and synthesis, J. Med. Chem. 55 (2012) 6391-6402.

[9] T. Grau, P. Selchow, M. Tigges, R. Burri, M. Gitzinger, E.C. Böttger, M. Fussenegger, P. Sander, Phenylethyl butyrate enhances the potency of second-line drugs against clinical isolates of Mycobacterium tuberculosis, Antimicrob. Agents Chemother. 56 (2012) 1142-1145.

[10] W. Weber, R. Schoenmakers, B. Keller, M. Gitzinger, T. Grau, M. Daoud-El Baba, P. Sander, M. Fussenegger, A synthetic mammalian gene circuit reveals antituberculosis compounds, Proc. Natl. Acad. Sci. U.S.A. 105 (2008) 99949998.

[11] X. Carette, N. Blondiaux, E. Willery, S. Hoos, N. Lecat-Guillet, Z. Lens, A Wohlkönig, R. Wintjens, S.H. Soror, F. Frénois, B. Dirié, V. Villeret, P. England, G. Lippens, B. Deprez, C. Locht, N. Willand, A.R. Baulard, Structural activation of the transcriptional repressor EthR from Mycobacterium tuberculosis by single amino acid change mimicking natural and synthetic ligands, Nucleic Acids Res. 40 (2011) 3018-3030.

[12] F. Markey, Principles of surface plasmon resonance, in: K. Nagata, H. Handa (Eds.), Real-Time Analysis of Biomolecular Interactions: Applications of BIACORE, Springer-Verlag, Tokyo, 2000.

[13] M.A. Cooper, Optical biosensors in drug discovery, Nat. Rev. Drug Discov. 1 (2002) 515-528.
[14] R. Karlsson, R. Halan, B. Joanne, S. Lesley, Practical aspects concerning direct detection of low molecular weight analytes using BIACORE(R) 2000, BIAjournal Special Issue (1997) 18-21.

[15] R.L. Rich, D.G. Myszka, Survey of the year 2006 commercial optical biosensor literature, J. Mol. Recognit. 20 (2007) 300-366.

[16] K. Robert, R. Halan, B. Joanne, S. Lesley, Practical aspect concerning direct detection of low molecular weight analytes using BIACORE 2000, BIAjournal Special Issue (1997) 1-17.

[17] M. Geitmann, K. Retra, G.E. de Kloe, E. Homan, A.B. Smit, I.J. de Esch, U.H Danielson, Interaction kinetic and structural dynamic analysis of ligand binding to acetylcholine-binding protein, Biochemistry 49 (2010) 8143-8154

[18] J.E. Gestwicki, H.V. Hsieh, J.B. Pitner, Using receptor conformational change to detect low molecular weight analytes by surface plasmon resonance, Anal. Chem. 73 (2001) 5732-5737.

[19] S. Mesch, D. Moser, D.S. Strasser, A. Kelm, B. Cutting, G. Rossato, A. Vedani, H. Koliwer-Brandl, M. Wittwer, S. Rabbani, O. Schwardt, S. Kelm, B. Ernst, Low molecular weight antagonists of the myelin-associated glycoprotein: synthesis, docking, and biological evaluation, J. Med. Chem. 53 (2010) $1597-$ 1615.

[20] D. Stokmaier, O. Khorev, B. Cutting, R. Born, D. Ricklin, T.O. Ernst, F. Böni, K. Schwingruber, M. Gentner, M. Wittwer, M. Spreafico, A. Vedani, S. Rabbani, O. Schwardt, B. Ernst, Design, synthesis and evaluation of monovalent ligands for the asialoglycoprotein receptor (ASGP-R), Bioorg. Med. Chem. 17 (2009) 7254 7264.

[21] M.C. Lo, A. Aulabaugh, G. Jin, R. Cowling, J. Bard, M. Malamas, G. Ellestad Evaluation of fluorescence-based thermal shift assays for hit identification in drug discovery, Anal. Biochem. 332 (2004) 153-159.

[22] D. Matulis, J.K. Kranz, F.R. Salemme, M.J. Todd, Thermodynamic stability of carbonic anhydrase: measurements of binding affinity and stoichiometry using ThermoFluor, Biochemistry 44 (2005) 5258-5266.

[23] D. Beckett, Regulating transcription regulators via allostery and flexibility, Proc. Natl. Acad. Sci. U.S.A. 106 (2009) 22035-22036.

[24] F. Frénois, A.R. Baulard, V. Villeret, Insights into mechanisms of induction and ligands recognition in the transcriptional repressor EthR from Mycobacterium tuberculosis, Tuberculosis (Edinburgh) 86 (2006) 110-114.

[25] F. Frénois, J. Engohang-Ndong, C. Locht, A.R. Baulard, V. Villeret, Structure of EthR in a ligand bound conformation reveals therapeutic perspectives against tuberculosis, Mol. Cell 16 (2004) 301-307.

[26] J.L. Ramos, M. Martínez-Bueno, A.J. Molina-Henares, W. Terán, K. Watanabe, X. Zhang, M.T. Gallegos, R. Brennan, R. Tobes, The TetR family of transcriptional repressors, Microbiol. Mol. Biol. Rev. 69 (2005) 326-356.

[27] S.E. Reichheld, Z. Yu, A.R. Davidson, The induction of folding cooperativity by ligand binding drives the allosteric response of tetracycline repressor, Proc. Natl. Acad. Sci. U.S.A. 106 (2009) 22263-22268.

[28] H. Sota, Y. Hasegawa, M. Iwakura, Detection of conformational changes in an immobilized protein using surface plasmon resonance, Anal. Chem. 70 (1998) 2019-2024. 